\title{
IMPLEMENTATTION OF CHILDREN'S FRIENDLY SCHOOL POLICY TO TACKLE THE CULTURE OF BRAWL IN THE MIDDLE SCHOOL (SMA) IN DKI JAKARTA
}

\author{
Lina Herlina ${ }^{a *}$, Asep Suryana ${ }^{b}$ \\ $a^{*}$ Universitas Pendidikan Indonesia \\ J1. Dr. Setiabudhi No. 229, Bandung, Indonesia, linaherllina@upi.edu \\ ${ }^{\mathrm{b}}$ Universitas Pendidikan Indonesia \\ Jl. Dr. Setiabudhi No. 229, Bandung, Indonesia, doef@upi.edu
}

\begin{abstract}
The purpose of this study is to identify the fight against brawl culture in high schools (SMA) through the implementation of character education in the Child Friendly School policy. The approach used is qualitative with the object of research teachers and principals. Data collection in this study uses interviews, observation and recommendation studies. Based on research results found that through good character education management that involves teachers and principals as examples in the application of character education, it can encourage students not to fight.
\end{abstract}

Keywords: brawls, character education, child friendly schools,

\section{INTRODUCTION}

One of the goals of education is to better humanize human beings, that is, through human knowledge they are able to solve problems in their lives in a more civilized way. Although with such a noble purpose, but reality often proves the opposite. It is precisely the students who are educated people not infrequently resolve conflicts with each other in a destructive way. Destruction of school facilities and public facilities, fights in public places, not a few were injured and even those who had to lose their lives. This shows students are still using primitive ways to solve the problem. The tradition of fighting between students, rampant violence and bloody brawls to the death and material that is not insignificant in the educational environment, especially among high schools (junior and senior high schools), until now still occur in some areas and schools.

Frequent brawls between groups of students from different schools, seen from the behavior in the form of verbal violence (mutilating, taunting and insulting), forms of physical violence (throwing stones, use of homemade bombs, use of homemade weapons, physical clashes between students with beatings, kicking, or stabbing), and forms of psychological violence (revenge, arrogance, and intimidation). [1] the phenomenon of student brawl which is part of the violence in the community is still happening. This phenomenon seems to be sustainable, where the object is the same but the culprit is switched from and to the next generation. Various segments of the 
community tried to find the cause and various experts thought put forward as an effort to find a solution to the solution, but the phenomenon of violence in this model continued. The phenomenon of brawl that occurs among students, this fact indicates that schools which are agents of change must act more progressively in educating the younger generation. Likewise, the role of family and environment is very significant in shaping the character of the young generation. . [2]. In terms of quantity, violence in the education world has so far not been able to be overcome in several areas, but all forms of policies, programs and activities have been rolled out to tackle brawl culture among students.

Student brawls are not the only form of violence in education, but there are many other forms, such as children who skip classes, are lazy to go to school, do not like certain subjects, and so on. All of these forms of violence may be invisible from the wrong communication patterns between the school world and students and the community in the school environment. Harmonization of relations between schools, students and the community is the key word to build a dignified education. Teachers tend not to be blamed when brawls occur between students and so does the community as parents guardians do not want to be blamed. They are both in the right position. [3]. Various attempts were made, especially for schools that have had a brawl culture for generations. Through the Child Friendly School policy that has been rolled out by the government, it is hoped that it will be able to tackle the brawl culture.

\section{METHODS}

This research method uses qualitative research. The subjects of this study were the principal and teachers at one of the high schools in DKI Jakarta, Indonesia, who implemented the Child Friendly School policy. Data collection methods used were interviews, observation, and documentation. This method consists of three components, namely data reduction, data presentation, and drawing conclusions..

\section{RESULTS AND DISCUSSION}

With the issuance of the Child Friendly School policy at the secondary school level, it can be expected to become a program that can prevent students from engaging in brawls

\section{A. Brawl}

The results should be clear and brief In Indonesia, brawl has become a tradition or even culture. Brawl is a fight or an act of violence committed by a group or a group of people. These social deviations are usually caused by trivial problems or can be caused by serious things that lead to clashes. Fighting has occurred since the creation of gang gangs among students and schools. Usually the animosity between schools starts from trivial matters. [4].

Brawl is an act that is not commendable and should not be done, brawlers are involved because of various reasons, namely because they are trapped in a brawl situation, a sense of solidarity, dam because of a senior invitation, and feel trapped in a brawl situation. In addition, by joining the brawl to be considered their group is solid and strong, so that the opponents deterrent, and uphold justice. [5]. According to the Big Indonesian Dictionary, brawls are crowded fights or mass fights. [6]. Fighting also means mass fighting (gang fight or mass fight) and as an act of collective violence (collective violence and is an act of collective violence). [7].

\section{B. Policy Implementation of Character Education}

Education can be interpreted as a conscious and planned effort to create an atmosphere of learning and learning process so that students actively develop their potential to have spiritual spiritual strength, self-control, personality, intelligence, noble character, and the skills needed by themselves, society, nation, and country . [8]. at least education has two functions. First, progressive function. In this function, educational activities can provide knowledge and development, instill values and skills to anticipate the future so that the nation's 
successors have the capability and readiness to face challenges in the present and the future. Second, conservative function. The conservative function of education is how to pass down and defend the ideals and culture of a society to future generations. [9] If the two functions of education are related to the existence and nature of human life, in essence education is directed to the formation of human personality. Namely, developing humans as individual beings, social beings, moral beings, and religious beings (religious). So it can be said that the main purpose of holding education is not to create intelligent and intellectual learners, but also aimed at building students' personalities.

Since the 2013 Curriculum was rolled out, the direction of education began to focus on character education. character education is the overall interpersonal relational dynamics with various dimensions, both from within and from outside him, so that the person can live his freedom, so he can be more responsible for his own growth as a person and other developments in their lives. Character education is not only dealing with the inculcation of values for students, but is a joint effort to create an educational environment where each individual can live his freedom as a prerequisite for a mature moral life.

Character education must be implemented from an early age, from elementary school to high school. Character education is an education system that aims to instill certain character values to students in which there is a component of knowledge, awareness or will, and actions to carry out these values. Character education is very closely related to moral education in which the aim is to shape and train the ability of individuals continuously in order to improve themselves towards a better life.

\section{Child Friendly School Policy}

A child-friendly school is a school that consciously seeks to guarantee and fulfill children's rights in every aspect of life in a planned and responsible manner. The main principle is non-discrimination of interests, the right to life and respect for children. Child Friendly Schools are one element in the application of character education. Here are some legal umbrella regarding Child Friendly Schools, which are as follows:

1. Regulation of the Empowerment of Women and Child Protection of the Republic of Indonesia No.8 2014 concerning Child Friendly School Policy

2. Instruction of the Governor of DKI Jakarta Province Number 16 Year 2015 Concerning Prevention and Handling of Bullying and Violence in School Environments (signed by Governor Basuki Tjahaja Purnama 29 January 2015) and Decree of the Head of the DKI Jakarta Provincial Education Office Number 860 of 2016 concerning Standard Operating Procedures for Handling Violence Students in the School Environment (Middle School, High School and Vocational School) Special Capital Region of Jakarta.

3. DKI Governor Regulation No.196 of 2015 concerning Guidelines for Integrated Public Space Management for Children

4. DKI Governor Regulation No.40 of 2016 concerning Management of Integrated Child Friendly Public Spaces

5. DKI Governor Regulation No.123 Year 2017 Regarding Management and Requirements for Facilities and Infrastructure of Child Friendly Integrated Public Spaces

6. Presidential Regulation Number 87 Year 2017 concerning Strengthening Character Education

7. Minister of Education and Culture Regulation 2018 No.20 About Strengthening Character Education in Formal Education Units

Child Friendly Schools are expected to be able to realize schools that are able to develop their talents, interests, knowledge attitudes of students at school. In addition, to prepare students to be able to work together, respect each other, love in their lives. And this policy needs to be socialized intensively to all schools because there is often the improper treatment of certain elements towards 


\section{Lina Herlina, et al. /Journal of Educational Administration Research and Review/Vol. 2 No. 2 December 2018}

students. From this socialization, it is expected that there will be an emphasis or prevention of acts of violence against children. With the Child Friendly School, it is expected that cases of student violence in schools will never happen again in Jakarta. Therefore teachers must really supervise their students while at school, both during study hours and at rest. The DKI Jakarta Government's Policy in Strengthening Character Education is to issue a "Child Friendly School" Policy. This policy has been socialized as follows:

1. Socialization of Child Friendly Schools on Lancang Island, Jakarta on Wednesday, October 23, 2019

2. The Government of South Jakarta City Declares Raman Anak School of SMAN 70 Jakarta on Monday, October 7, 2019

3. The Mayor of East Jakarta Promotes Child Friendly Schools at East Jakarta Mayor's Office on November 12, 2015

4. SMAN 29 Jakarta became a reference for Child Friendly Schools by the Minister of Women's Empowerment and Child Protection, Yohana Susana Yembise on Thursday, April 23, 2015

From the policies that have been rolled out by the Ministry of Education on Strengthening Character Education, the Ministry of Empowerment and Child Protection on Child Friendly Schools, DKI Jakarta Governor Regulation on Management of public spaces and facilities and infrastructure of Child Friendly Schools, can make students learn safely and comfortably while they are at at school, this can be a motivating factor for students not to be involved in brawls, due to their busy school activities and safe and pleasant school environment. High school level (SMA) in DKI Jakarta, which has proclaimed itself as a pilot school Child Friendly School Policy, due to several factors:

\section{The Role of Principal}

Principals as leaders must be able to make good planning, organizing, implementing and monitoring their policies including Child Friendly Schools. The Principal conducts innovations in order to become a pilot school, role model, and so on, so that all parties are committed to change and the best, and the most important is a change in "behavior". No more punishment for brawling children, but given coaching. Innovating on the beauty, appearance and cleanliness of the environment inside and outside the classroom, toilets, and so on. So that there is no longer the view that high school is a school that often brawls, the school made a motto: "Happy children, Quiet Teachers, Happy Parents".

\section{Teacher's Role}

The teacher's task besides teaching, is also involved in the organizational structure and management of the school. In this case, especially teachers who get additional assignments as student representatives, BP / BK teachers, Religious teachers, play an important role in handling brawl cases. Therefore, these teachers must continue to learn and innovate in their assignments, and set an example for students in the application of character education.

\section{CONCLUSION/RECOMENDATION}

Whatever policies are rolled out to tackle brawl, there are a number of roles that play an important role in realizing Child Friendly Schools to tackle brawls, namely:

1. Leadership in school leaders who are innovative, changeable, professional and authoritative

2. The involvement of teachers in various activities in schools that do not look at the time must always accompany students

3. Creating a friendly school environment, such as painting school walls using the mural method. Colorful school fences and chairs, literacy parks, parks and mini waterfalls, and so on

4. Doing awards for students who excel and coaching students who do deviations

By implementing the Child Friendly school policy, it is expected to be able to eliminate the culture of fighting, because students already feel safe, comfortable, and happy while in the school environment 
Lina Herlina, et al. / Journal of Educational Administration Research and Review /Vol. 2 No. 2

December 2018

\section{REFERENCES (Examples)}

Ahmad Janan Asifudin, 2010, Mengungkit Pilar-Pilar Pendidikan

Anwar Arifin, 2003, Memahami Paradigma Baru Pendidikan Nasional

dalam Undang-Undang Sisdiknas, Jakarta: Depag RI

Eko Setiawan, 2015, Peran Guru Bimbingan Konseling dalam Mengatasi Tawuran Pelajar, Psikoislamika, Jurnal Psikologi Islam (JPI), Pusat Penelitian dan Layanan Psikologi, Vo.12, Nomor. 2

Islam: Sebuah Tinjauan Filosofis, Yogyakarta: UIN Suka Press.

Kurniati Zainudin, dkk, 2013, Mengapa Kami Tawuran? Tawuran dari Kacamata Pelaku, Jurnal Psikologi, Vol.18, No.1

Kurniati Zainudin, dkk, 2013, Mengapa Kami Tawuran, Psikologi, Vol.18, Nomor.1
M.Ahyar Fadly, 2012, Reorientasi Peran Guru PAI untuk Menghentikan Kekerasan di Dunia Pendidikan, El-Hikam (Jurnal Pendidikan dan Kajian keislaman), Vol.V, No.1, Januari-Juni 2012

Makassar. Diskusi Ihwal Kemahasiswaan Makassar

Markum, 2005, Memahami Tindak Kekerasan Kolektif Mahasiswa

Media Press

Tim Prima Pena, 2002, Kamus Besar Bahasa Indonesia, Jakarta: Gita

Warih Anjari, 2012, Tawuran Pelajar dalam Perspektif Kriminologis, Hukum Pidana, dan Pendidikan, Widya, Tahun 29 No.324 September-Oktober 2012 